\title{
ARAŞTIRMA/RESEARCH
}

\section{ASSESSMENT OF EXPERIENCED FEAR OF BIRTH AND PARENTING BEHAVIOR IN EARLY POSTPARTUM PERIOD}

\author{
Kevser ÖZDEMIR ${ }^{1}$ iD $\quad$ Yasemin BAŞKAYA ${ }^{2}$
}

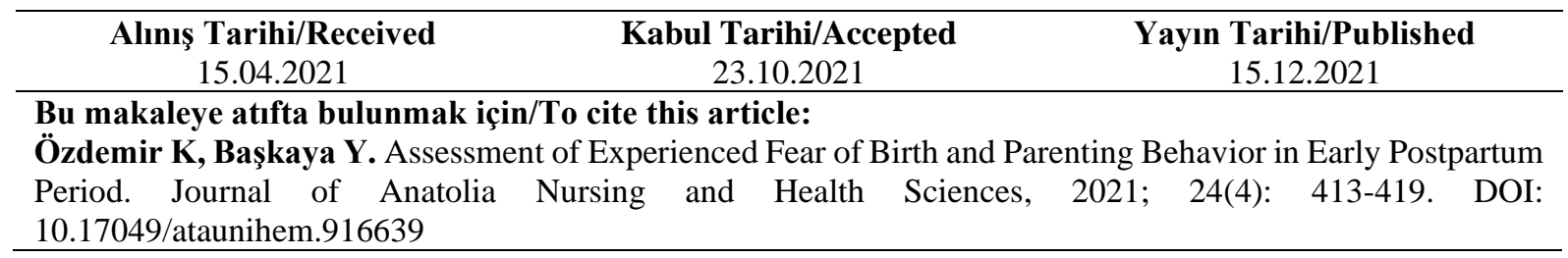

\section{ABSTRACT}

Aim: This study was conducted to evaluate of relationship between fear levels of birth and parenting behaviors of mothers in early postpartum periods and to determine some demographic factors that affected this.

Method: This study is a cross-sectional study carried out between January and April 2018 in Sakarya. Inclusion criteria for study are women in the Postpartum Service who had vaginal delivery and in postpartum first 4 hours. Student T test, One Way Anova and Pearson Correlation Analysis were performed with the help of Statistical Package for Social Sciences (SPSS) program. Statistical significance was accepted as $p<0,05$.

Results: The age of the study group ranged from 18 to 42 years with an average of $27.25 \pm 5.19$ years. The mean score for the Wijma Delivery Expectancy / Experience Questionnaire B version was $107.76 \pm 15.00$ and the mean score for the Postpartum Parenting Behavior Scale was 4.26 1.05 . There was no relationship between maternal birth experienceand early postpartum parenting behaviors ( $r=-0.072 ; p=0.108)$.

Conclusions: There was no relationship between maternal experiences of birth and early parenting behaviors. However, it was determined that mothers had a clinical level of fear at birth, whereas the mean level of early parenting behaviors was moderate.

Keywords: Fear of birth; parenting behavior; postnatal care.

\section{$\ddot{O} Z$}

Annelerin Doğum Korkusu Yaşama Düzeyleri ile Erken Postpartum Dönemde Ebeveynlik Davranuşlart Arasındaki İlişsinin Değerlendirilmesi

Amaç: Bu çallşma, doğum korkusu yaşama düzeyleri ile erken postpartum dönemde ebeveynlik davranışları arasındaki iliş̧kiyi değerlendirmek ve etkileyen bazı demografik faktörleri belirlemek amacıyla yapıld.

Yöntem: Çalışma, Ocak- Nisan 2018 tarihleri arasında Sakarya ilinde kamu hastanelerinin Lohusa Servisinde yatmakta olan, vajinal doğum yapan ve doğumun 4. Evresindeki kadınlar üzerinde gerçekleştirilen kesitsel tipte bir araş̧tırmadır. Veriler, bilgisayar ortamında değerlendirilmiş olup, analizler için student T testi, One Way Anova ve Pearson Korelasyon Analizi kullanıld. İstatistiksel anlamlıllk değeri olarak $p<0.05$ kabul edildi.

Bulgular: Çalışma grubunu oluşturanların yaşları 18-42 arasında değişmekte olup, ortalama 27.25 \pm 5.19 yll idi. Wijma Doğum Beklentisi/Deneyimi Ölçeği B Versiyonu'ndan aldıkları puan ortalaması 107.76士15.00, Doğum Sonrası Ebeveynlik Davranışı Ölçeği'nden aldıkları puan ortalaması $4.26 \pm 1.05$ olarak bulundu. Annelerin yaşadıkları doğum deneyimi ve erken postpartum dönemde ebeveynlik davranışları arasında iliş̧ki saptanmadı $(r=-0.072 ; p=0.108)$.

Sonuç: Annelerin yaşadıkları doğum deneyimleri ile erken dönemde ebeveynlik davranışları arasında herhangi bir iliş̧ki saptanamadl. Ancak, annelerin doğumda klinik düzeyde korku yaşadıkları buna karşın erken dönemde ebeveynlik davranışı puan ortalamasının orta düzeyde olduğu belirlendi.

Anahtar Kelimeler: Doğum korkusu; ebeveyn davranışı; doğum sonrası bakım.

1 Corresponding Author: Sakarya University, Faculty of Health Sciences, (Asst. Prof), ORCID: 0000-00024900-9095, e-posta: kevserozdemir@ sakarya.edu.tr

${ }^{2}$ Sakarya University, Faculty of Health Sciences, (Asst. Prof), ORCID: 0000-0002-1533-8667, e-posta: yhamlaci@sakarya.edu.tr 


\section{INTRODUCTION}

Fear of birth is defined as fear before birth, during and after delivery (1). Fears associated with birth are pain, obstetric damage, urgent cesarean requirement or death during childbirth. Lack of trust in healthcare personnel to assist birth increases fears (2). Today, the basic approach regarding pregnancy and birth is that birth is a physiological process and requires very little medical intervention. However, from time to time, negative experiences at the time of birth can take its place among the birth stories told for many years. The spread of such experiences by sharing among women, as well as the painful birth scenes shown in visual media, create a negative birth image. Therefore, the image related to the fact that birth is a painful, bloody, frightening event makes women think that they will experience this frightening experience about the vaginal birth $(3,4)$.

Since the early period after birth is the most intense period of attachment, it is the most appropriate time to initiate a positive mother-baby relationship $(5,6)$. In the first encounter after birth, the behaviors of the mother or father towards the baby are accepted as the first parenting behavior. These behaviors shown by the parent are behaviors such as touching and caressing the baby's hands and feet, talking to the baby, making eye contact, examining the baby $(7,8)$. The behaviors of the mother towards her baby in the first meeting after birth give important clues about the attachment process between mother and baby in the future.

\section{AIM}

Although there are studies in our country about the fear of birth and evaluation of parental behaviors in the early postpartum period, no studies investigating the relationship between the fear of birth experienced by mothers and parenting behaviors in the early postpartum period have been encountered. For this reason, this study was conducted to evaluate the relationship between the level of fear of birth and parenting behavior in the early postpartum period and to determine some of the demographic factors affecting it.

\section{METHODS}

Study Design and Setting: The study was planned as a descriptive cross-sectional study in order to examine the relationship between mothers' level of fear of birth and their parental behavior in the early postpartum period.

Participants: The population of the study consisted of women who made vaginal delivery and at the 4th stage of the birth is between January and April 2018, in Sakarya Education and Research Hospital Central Campus and in Postpartum Service of Maternity and Child Campus, between January and April 2018. The sample of the study consisted of 495 women who volunteered to participate in the research and did not have communication problems. Women who are illiterate, under 18 years of age, pregnant with in vitro fertilization and multiple pregnancy were not included in the study.

Data Collections: Interviews were held with mothers in the postpartum service. After being informed about the subject and purpose of the study, verbal consent was obtained from the mothers who agreed to participate in this study. The previously prepared questionnaires were filled in by the mothers under supervision. This process took about 15-20 minutes. During the data collection phase, the rules in the Helsinki Declaration were acted upon.

Measures: The questionnaire form, prepared by using the literature in accordance with the purpose of the study, was collected by face-to-face interview technique using the Wijma Birth Expectation / Experience Scale B Version and Postpartum Parenting Behavior Scale. The questionnaire includes questions including sociodemographic characteristics such as age, education level, occupation of the pregnant woman, and information such as gestational week and number of births.

Wijma Birth Expectation / Experience Scale- Version $B(W-D E Q / V e r s i o n ~ B)$ : It was developed by Wijma et al. (1) to measure the fear of birth experienced by women. The scale, which was adapted to Turkish by Uçar et al. (9), consists of 33 items. The answers in the scale are numbered from 1 to 6 , and are in six-point Likert type. 1 is expressed as "completely" and 6 as "none". While the minimum score on the scale is 33, the maximum score is 198. As the score increases, the fear of birth experienced by women increases. Questions numbered 2, 3, 6, 7, 8, 11, $12,15,19,20,24,25,27,31$ are calculated by reversing.

Postpartum Parenting Behaviour Scale: It was developed by Britton et al. (10) to evaluate the parenting behavior of the parents towards their baby during their first encounter with the baby after birth. During the validity and reliability study for adaptation in Turkish, in the application of the scale conducted by Çalışır et al. (7), the observer observes the behaviors of the parent 
towards her baby during the first 10 minutes after the parent and the baby minus the existing (+) and non-positive behavior (-) by putting the sign. Each item is rated as one (1) score if behavior is observed, and zero (0) if no behavior is observed. The total scale score consists of the sum of the numbers obtained from each item. The total score of the scale is between 0 and 6 points. The high total score obtained from the scale shows that the parent has a more positive parenting behavior towards her baby (7).

Required Approvals: Written consent has been obtained for the study from the Ethics Board of Faculty of Medicine of Sakarya University (Date: 2019/ Number: 71522473.050.01.04/129). Written permission was obtained from Training and Research Hospital in order to conduct the research. First verbal consent and then written consent was obtained from the women who met the sample criteria after explanation of the study verbally.

Statistical Analysis: The data were evaluated in computer environment, student $\mathrm{T}$ test, One Way Anova and Pearson Correlation Analysis were used for the analyzes. P $<0.05$ was accepted as the statistical significance value.

\section{FINDING AND DISCUSSION}

The ages of the women constituting the study group vary between 18 and 42, with an average of $27.25 \pm 5.19$ years. The scores they got from the Wijma Birth Expectation / Experience Scale B Version varies between 58 and 137, with an average of $107.76 \pm 15.00$. The distribution of the average scores of the study group in the Wijma Birth Expectation / Experience Scale B Version according to some socio-demographic characteristics are given in Table 1.

Tablo 1. The Distribution of the Scores of the Study Group from the Wijma Birth Expectation / Experience Scale B Version According to Characteristics

\begin{tabular}{lclclc}
\hline Characteristics & $\mathbf{n}$ & $\mathbf{O r t} \pm \mathbf{S S}$ & $\begin{array}{c}\text { Test value } \\
\text { F/T; } \mathbf{p}\end{array}$ & $\begin{array}{l}\text { Multiple } \\
\text { Comparisons }\end{array}$ & $\mathbf{p}$ \\
\hline Education Status & & & & & \\
Literate (1) & 128 & $100.16 \pm 1.70$ & & $\mathbf{1 - 2}$ & $\mathbf{0 . 0 0 0}$ \\
Primary School (2) & 149 & $110.15 \pm 1.11$ & $\mathbf{1 6 . 3 1 2 ;} \mathbf{0 . 0 0 0}$ & $\mathbf{1 - 3}$ & $\mathbf{0 . 0 0 0}$ \\
Middle School(3) & 130 & $111.37 \pm 1.28$ & & $\mathbf{1 - 4}$ & $\mathbf{0 . 0 0 0}$ \\
High School and above (4) & 88 & $110.06 \pm 0.97$ & & $2-3$ & 0.926 \\
- & - & - & & $2-4$ & 1.000 \\
- & - & - & & $3-4$ & .904 \\
\hline Employment & & & & - & - \\
Employed & 394 & $106.64 \pm 15.91$ & $\mathbf{2 2 . 2 8 3 ; 0 . 0 0 0}$ & - & - \\
Unemployed & 101 & $112.11 \pm 9.67$ & & & \\
\hline Family Type & & & & $1-2$ & 0.101 \\
Nuclear Family & 263 & $109.54 \pm 11.93$ & $\mathbf{1 8 . 2 2 9} ; \mathbf{0 . 0 0 6}$ & $\mathbf{1 - 3}$ & $\mathbf{0 . 0 4 9}$ \\
Extended Family & 232 & $105.73 \pm 17.67$ & & & \\
\hline
\end{tabular}

W-DEQ scores are evaluated in four subgroups: those with low birth fear (W-DEQ score $\leq 37$ ), those with moderate birth fear (with W-DEQ score between 38-65), women with severe fear of birth (W-DEQ score 66-84), and clinical birth women who have a fear (W-DEQ score $\geq 85$ ) (1). In a study conducted in the Netherlands, the proportion of those who had clinical fear of birth was found as $12 \%$ (11). In another study conducted in Italy, it was determined that $14.2 \%$ of women in childbirth had clinical fear of birth (12). In our study, the rate of mothers who had clinical fear of birth is determined as $91.9 \%$.

According to our research, a significant relationship is found between education and fear of birth. In women with low education level, the level of fear of delivery is found to be statistically significant $(\mathrm{p}<0.05)$. In Uçar's (9) study, it was determined that fear of birth increased as the level of education increased (9). A study conducted abroad has shown that fear of birth increases with the increase in the level of education (2). This situation makes us think that the information not gained from health professionals brings fear along with it.

In the studies conducted in the past, it was determined that fear of birth was higher in mothers with low socio-economic level (13-16). According to our study findings, the level of fear of birth is higher in women who does not work ( $p$ $<0.05)$. However, in a study conducted in India, the level of fear of birth was higher among women working in an income generating job (17). Likewise, in another study conducted in Australia, fear of birth was found higher in working women 
(18). On the other hand, the study carried out in Iran could'nt find a relation between women's income and employment status, and fear of birth (19). The differences in the results of the study may be caused by the time measured, personal and cultural factors.

One of the mechanisms to cope with fear of birth is social support $(20,21)$. In studies conducted with spouses, who are the primary social support mechanisms of pregnant women, it was determined that spouses also experienced fear of birth $(22,23)$. Therefore, the extended family structure is thought to be effective in dealing with fear. According to our study findings, the level of fear of birth is higher in those with nuclear family structure ( $\mathrm{p}<0.05)$. In addition to studies reporting that there was no relationship between family type and fear of birth, there are also studies reporting that women with extended family structure have lower fear of birth $(20,21,24)$.

Table 2 shows the intrapartum and postpartum variables by experienced fear of birth. The mean score for the Wijma Delivery Expectancy/Experience Questionnaire B version was found to be statistically significantly birth method, defined the birth process as "very difficult and bad", did not breastfeed after birth and did not adapt to the mother after delivery (for each; $\mathrm{p}<0.05)$.

Table 2. The Distribution of The Scores of The Study Group From The Wijma Birth Expectation / Experience Scale B Version According to Some İntrapartum and Postpartum Variables

\begin{tabular}{|c|c|c|c|c|c|}
\hline Variables & $\mathbf{n}$ & Ort \pm SS & $\begin{array}{l}\text { Test value } \\
\text { F/T; } p\end{array}$ & $\begin{array}{l}\text { Multiple } \\
\text { Comparisons }\end{array}$ & $\mathbf{p}$ \\
\hline Delivery Method & & & \multirow{4}{*}{$8.820 ; 0.000$} & & \\
\hline Non-invasive & 99 & $104.74 \pm 16.67$ & & $1-2$ & 0.012 \\
\hline Episiotomy & 341 & $109.56 \pm 14.43$ & & $1-3$ & 0.51 \\
\hline Induced labor & 55 & $101.98 \pm 13.19$ & & $2-3$ & 0.001 \\
\hline \multicolumn{6}{|l|}{$\begin{array}{l}\text { Perception of experienced } \\
\text { delivery period }\end{array}$} \\
\hline Very hard and very bad (1) & 220 & $112.60 \pm 0.84$ & \multirow{3}{*}{$39.329 ; 0.000$} & $1-2$ & 0.001 \\
\hline Quite hard and bad (2) & 170 & $107.57 \pm 0.88$ & & $1-3$ & 0.000 \\
\hline A bit hard (3) & 105 & $97.91 \pm 1.92$ & & $2-3$ & 0.000 \\
\hline \multicolumn{6}{|l|}{$\begin{array}{l}\text { First breastfeeding } \\
\text { experince }\end{array}$} \\
\hline $\begin{array}{l}\text { Didn't experience let-down } \\
\text { and couldn't breastfeed(1) }\end{array}$ & 126 & $109.83 \pm 1.06$ & \multirow{3}{*}{$4.318 ; 0.014$} & $1-2$ & 0.995 \\
\hline $\begin{array}{l}\text { Experienced let-down but } \\
\text { couldn't breastfeed(2) }\end{array}$ & 98 & $110.03 \pm 0.98$ & & $1-3$ & 0.043 \\
\hline $\begin{array}{l}\text { Experienced let-down and } \\
\text { breastfed (3) }\end{array}$ & 271 & $105.97 \pm 1.06$ & & $2-3$ & 0.050 \\
\hline \multicolumn{6}{|l|}{$\begin{array}{l}\text { Adapting to the role of } \\
\text { motherhood }\end{array}$} \\
\hline Couldn't adapt at all (1) & 20 & $120.85 \pm 0.48$ & \multirow{6}{*}{$9.214 ; 0.000$} & $1-2$ & 0.000 \\
\hline Adapted it a bit (2) & 215 & $106.78 \pm 1.03$ & & $1-3$ & 0.000 \\
\hline Adapted it generally (3) & 208 & $106.07 \pm 1.03$ & & $1-4$ & 0.224 \\
\hline Adapted it quite well (4) & 52 & $113.48 \pm 2.00$ & & $2-3$ & 0.959 \\
\hline - & - & - & & $2-4$ & 0.017 \\
\hline- & - & - & & 3-4 & 0.006 \\
\hline Total & 495 & $107.76 \pm 15.00$ & - & - & - \\
\hline
\end{tabular}

One of the main underlying factors of fear of birth is episiotomy (25). Studies have also reported that episiotomy significantly increases the fear of birth (17,26-28). According to our study findings, the level of fear of birth is higher in women who underwent episiotomy in labor ( $p$ $<0.05$ ). Our study result is in line with the literature.
In our study in those who expressed their birth process as "very difficult and very bad", the level of fear of birth is found higher ( $\mathrm{p}<0.05)$. In a study where birth experience was performed, it was determined as a high risk factor for fear of birth (29). Again, studies have reported that negative birth experience increases fear of birth 
(30). The fact that birth is already feared for its difficulty and badness further reinforces the fear of birth of women.

For the continuity of lactation, the psychology of your mother, especially in the early stage of puerperium, is of great importance. It is reported that fear and stress experienced during labor can affect the neurobehavior and vigilance of the newborn. Accordingly, mothers with high fear of birth are expected to experience more breastfeeding problems. The fear experienced will also affect the peacefulness of the mother in the early period and her compliance with the role of motherhood (31-33). In a prospective study, it was found that breastfeeding problems were more common in mothers exposed to fear and stress during labor (34). In our study, the level of fear of birth was found higher in women who could not breastfeed their babies in the early postpartum period and stated that they could not adapt to the role of motherhood ( $\mathrm{p}<0.05)$.

The average score of the mothers on the
Postpartum Parenting Behavior Scale was found to be $4.26 \pm 1.05$, and no relationship between parental behaviors in the postpartum period and their birth experience was detected $(r=-0.072 ; \mathrm{p}$ $=0.108)$. The distribution of the scores of the study group got from the Wijma Birth Expectation/ Experience Scale B Version and the scores obtained from the Postpartum Parenting Behavior Scale are presented in Chart 1. In the study conducted by Özkan et al. (8), the average score was found to be $3.20 \pm 1.95$. In the other study, it was determined that the average score was $4.68 \pm 1.34$ (35). The highest score obtained from the Postpartum Parenting Behavior Scale is 6 . The high total score obtained from the scale shows that the parent has a more positive parenting behavior towards her baby (7). It is seen that the scores obtained in this research are at a good level. This situation suggests that the mothers embrace their babies after the birth and switch to the baby care process and leave aside their negative experiences and fears during labor.

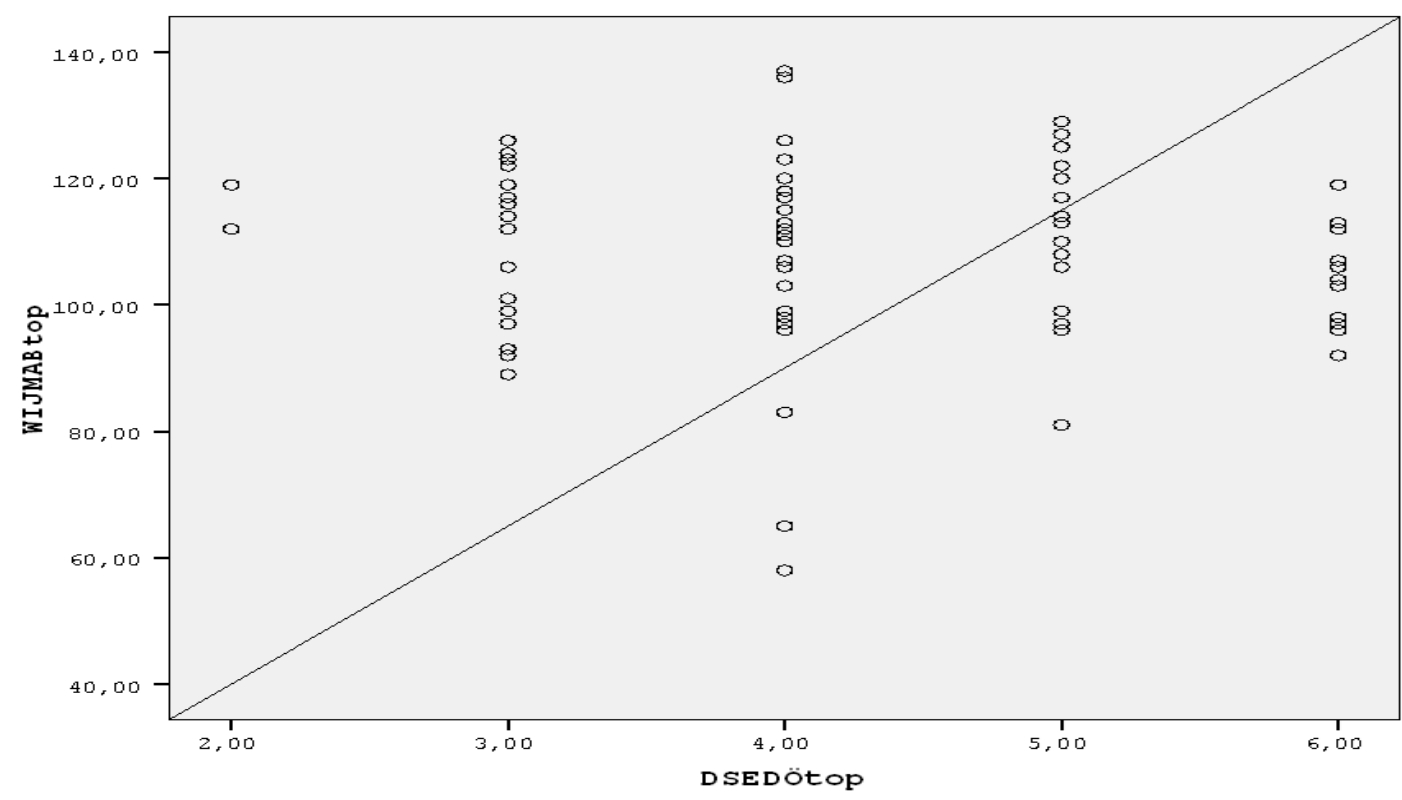

Chart 1. The distribution of the scores of the study group from the Wijma Birth Expectation / Experience Scale B Version and the scores they got from the Postpartum Parenting Behavior Scale

Limitations: The limitations of the study may include the facts that it is a cross-sectional study and it was conducted only on women presented to a single hospital.

\section{CONCLUSION}

It was determined that mothers experience clinical fear of birth. It is suggested that pregnant women in labor should not only be evaluated their physical assessments, but also by their mental states, and their fears about birth should be detected by midwives and midwifery attempts for these fears should be planned in time.

Acknowledgments: The authors would like to thank the married women who were willing to participate in the study.

Conflict of Interest Statement: The authors have stated explicitly that there are no conflicts of interest in connection with this article.

Authors' Contributions: Study concept and design ÖK; Acquisition of subjects and data: 
BY; Analysis and interpretation of data: BY; Preparation of manuscript: OK, BY. All the

\section{REFERENCES}

1. Wijma K, Wijma B, Zar M. Pyschometric aspects of the W-DEQ; A new questionnaire for the measurement of fear of childbirth. Journal of Psychosomatic Obstetrics \& Gynecology 1998;19:84-97.

2. Melender HL. Experiences of fears associated with pregnancy and childbirth: a study of 329 Pregnant Women. Birth. 2002; 29 (2):101-11.

3. Sayıner FD, Özerdoğan N. Doğal doğum. Maltepe Üniversitesi Hemşirelik Bilim ve Sanatı Dergisi. 2009; 2(3):143-8.

4. Serçekuş P. Doğum korkusuna müdahele: Hypnobirthing. TAF Preventive Medicine Bulletin. 2011; 10(2): 239-42.

5. Özkan H, Polat S. Annelik davranışını öğrenme süreci ve hemşirelik desteği. Bozok Tip Dergisi. 2011;1(3):35-9.

6. Taşkın L. Doğum ve Kadın Sağlı̆̆ Hemşireliği. 10. Bask1, Ankara: Sistem Ofset Matbaacilik. 2011.

7. Çalışır H, Karacam Z, Akgül AF, Kurnaz DA. Doğum Sonrası Ebeveynlik Davranışı Ölceği'nin Türkce formunun geçerlik ve güvenirliği. Atatürk Üniversitesi Hemşirelik Yüksekokulu Dergisi. 2009; 12(1): 1-8.

8. Özkan H, Kanbur A, Apay S, Kılıç M, Ağapınar S, Özorhan EY. Annelerin doğum sonu dönemde ebeveynlik davranışlarının değerlendirilmesi. Şişli Etfal Tip Bülteni. 2013; 47(3): 117-21.

9. Uçar E. Wijma Doğum Beklentisi /Deneyimi Ölçeği B Versiyonu'nun Geçerlik ve Güvenirlik Çalışması. Haliç Üniversitesi Sağlık Bilimleri Enstitüsü. Yükseklisans Tezi. 2013.

10. Britton HL, Gronwaldt V, Britton JR. Maternal postpartum behavior and motherinfant relationship during the first of life. The Journal of Pediatrics. 2001; 138, 905-9.

11. Logtenberg SL, Verhoeven CJ, Rengerink KO, Sluijs AM, Freeman LM, Schellevis FG, Mol BW. Pharmacological pain relief and fear of childbirth in low risk women; secondary analysis of the RAVEL study. BMC Pregnancy and Childbirth. 2018;18(1):347.

12. Calderani E, Giardinelli L, Scannerini S, Arcabasso S, Compagno E, Petraglia F, Ricca V. Tocophobia in the DSM-5 era: Outcomes of a new cut-off analysis of the authors contributed to the writing of the paper. All authors read and approved the final manuscript.

Wijma delivery expectancy/experience questionnaire based on clinical presentation. Journal of Psychosomatic Research. 2019; 116: 37-43.

13. Saisto T, Salmela-Aro K, Nurmi JE, Halmesmäki E. Psychosocial characteristics of women and their partners fearing vaginal childbirth. BJOG: International Journal of Obstetric \& Gynaecology. 2001;108: 492-8.

14. Waldenström U, Hildingsson I, Ryding EL. Antenatal fear of childbirth and its association with subsequent caesarean section and experience of childbirth. BJOG: An International Journal of Obstetrics and Gynaecology 2006; 113(6): 638-46.

15. Laursen M, Hedegaard M, Johansen C. Fear of childbirth: predictors and temporal changes among nulliparous women in the Danish National Birth Cohort. BJOG: An International Journal of Obstetrics and Gynaecology. 2008; 115(3): 354-60.

16. Çiçek Ö, Mete S. Sık Karşıllaşılan Bir Sorun: Doğum Korkusu. Dokuz Eylül Üniversitesi Hemşirelik Fakültesi Elektronik Dergisi. 2015; 8(4): 263-8.

17. Jha P, Larsson M, Christensson K, Svanberg AS. Fear of childbirth and depressive symptoms among postnatal women: A crosssectional survey from Chhattisgarh, India. Women and Birth. 2018; 31(2): e122-33.

18. Toohill J, Fenwick J, Gamble J, Creedy DK. Prevalence of childbirth fear in an Australian sample of pregnant women. BMC Pregnancy and Childbirth. 2014;14(1):275.

19. Soltani F, Eskandari Z, Khodakarami B, Parsa P, Roshanaei G. Factors contributing to fear of childbirth among pregnant women in Hamadan (Iran) in 2016. Electronic Physician Journal. 2017; 9(7):4725.

20. Şen E, Şirin A. The Factors Affecting the Level of Anxiety, Depression and Perceived Support of the Pregnant Women Diagnosed with Preterm Labor. Gaziantep Medical Journal. 2013; 19(3):159-63.

21. Gao LL, Liu XJ, Fu BL, Xie W. Predictors of childbirth fear among pregnant Chinese women: A cross-sectional questionnaire survey. Midwifery. 2015; 31(9): 865-70.

22. Hildingsson I, Johansson M, Fenwick J, Haines H, Rubertsson C. Childbirth fear in expectant fathers: Findings from a regional 
Swedish cohort study. Midwifery. 2014; 30(2):242-7.

23. Bergström M, Rudman A, Waldenström U, Kieler H. Fear of childbirth in expectant fathers, subsequent childbirth experience and impact of antenatal education: Sub analysis of results from a randomized controlled trial. Acta Obstetricia et Gynecologica Scandinavica. 2013; 92(8):967-73.

24. Phunyammalee M, Buayaem $T$, Boriboonhirunsarn D. Fear of childbirth and associated factors among low-risk pregnant women. Journal of Obstetrics and Gynaecology. 2019; 39(6):763-7.

25. El-Aziz SNA, Mansour SES, Hassan NF. Factors associated with fear of childbirth: It's effect on women's preference for elective cesarean section. Journal of Nursing Education and Practice. 2017;7(1):133-46.

26. Fairbrother N, Thordarson DS, Stoll K. Fine tuning fear of childbirth: The relationship between Childbirth Fear Questionnaire subscales and demographic and reproductive variables. Journal of Reproductive and Infant Psychology. 2018;36(1):15-29.

27. Demšar K, Svetina M, Verdenik I, Tul N, Blickstein I, Velikonja VG. Tokophobia (fear of childbirth): Prevalence and risk factors. Journal of Perinatal Medicine. 2018;46(2):151-4.

28. Striebich S, Mattern E, Ayerle GM. Support for pregnant women identified with fear of childbirth (FOC)/tokophobia-a systematic review of approaches and interventions. Midwifery. 2018; 61: 97-115.
29. Handelzalts JE, Becker G, Ahren M P, Lurie S, Raz N, Tamir Z, Sadan O. Personality, fear of childbirth and birth outcomes in nulliparous women. Archives of gynecology and obstetrics. 2015;291(5):1055-62.

30. Sluijs AM, Cleiren MPHD, Scherjon SA, Wijma K. No relationship between fear of childbirth and pregnancy-/deliveryoutcome in a low-risk Dutch pregnancy cohort delivering at home or in hospital. Journal of Psychosomatic Obstetrics \& Gynecology. 2012;33(3):99-105.

31. Alehagen S, Wijma K, Wijma B. Fear during labour. Acta Obstetricia et Gynecologica Scandinavica. 2001;80(4):315-20.

32. Hill PD, Aldag JC, Chatterton RT. İnitiation and frequency of pumping and milk production in mothers of non-nursing preterm infants. Journal of Human Lactation 2001;17(1):9-13.

33. Tatarlar A, Tokat M. Vajinal doğum sırasında yaşanan korkunun laktasyona, emme davranışlarına ve ilk emzirme sonuçlarına etkisi. TAF Preventive Medicine Bulletin. 2016;15(2):83-91.

34. Chapman DJ, Perez-Escamilla R. Maternal perception of the onset of lactation is a valid, public health indicator of lactogenesis stage II. The Journal of Nutrition. 2000; 130:297280.

35. Koç Ö, Özkan H, Bekmezci H. Evaluating the correlation between maternal role and parenting behavior. İzmir Dr. Behçet Uz Çocuk Hastanesi Dergisi. 2016;6(2):143-50. 